\title{
“LADANG SUDAH MENGUNING DAN SIAP UNTUK DITUAI"
}

(Yohanes 4:35)

\section{Oleh:}

\section{Pdt. Dr. G. Sudarmanto, D.Th}

\section{Pendahuluan:}

Tema tentang 'penuaian' makin marak diekspose di kalangan masyarakat Kristen di akhir zaman ini. Hal itu didorong oleh semangat yang kuat untuk taat kepada Amanat Agung Tuhan Yesus Kristus untuk menjadikan sekalian bangsa murid-Nya (Mat 28:19-20). Pada umumnya, penuaian dipahami sebagai sebuah tantangan, pengharapan dan kenyataan. Penuaian sebagai tantangan karena proses penuaian memerlukan perjuangan dan kerja keras. Penuaian sebagai pengharapan karena tuaian yang dimaksud merupakan keadaan yang diharapkan akan terjadi. Penuaian sebagai kenyataan karena faktanya 'penemuan dan pemenangan' jiwa baru terus sedang berlangsung di seluruh bagian muka bumi ini.

Teks Yohanes 4:4-42 menuturkan perjumpaan dan percakapan Yesus dengan seorang perempuan Samaria di sumur Yakub. Dari dialog tersebut kita dapat memahami Lima Pokok penting terkait dengan 'penuaian' yang meliputi siapa yang menuai? Dimana dituai? Siapa yang dituai? Bagaimana Strategi Penuaian? Apa hasil/dampak penuaian itu?

1. Sang Penuai. Dalam konteks ini Sang Penuai itu adalah Yesus Kristus sendiri dan yang dituai ialah perempuan Samaria. Secara personal terdapat beberapa perbedaan (pertentangan) di antara keduanya. Pertama, perbedaan 'gender' yaitu antara laki-laki dan perempuan. Hal ini dapat menjadi isu serius dalam konteks budaya setempat, bahwa ada seorang laki-laki 
berbicara berdua di tempat yang sepi. Kedua, perbedaan 'etnis' yaitu Yesus sebagai orang Yahudi sedangkan perempuan itu adalah orang Samaria. Kedua suku ini telah lama menjadi musuh 'bebuyutan' akibat kesalahan nenek moyang mereka di masa lampau. Ketiga, perbedaan kepercayaan (teologis). Meski mereka berasal dari tradisi nenek moyang yang sama, yaitu anak-anak Yakub, namun sejarah pembuangan pada masa lampau telah membuat orang Samaria berasimilasi dengan kepercayaan bangsa-bangsa lain. Ketika mereka kembali ke tanah perjanjian, ada perbedaan pandangan tentang pusat penyembahan kepada Allah Israel. Namun demikian, ketiga perbedaan tersebut bukan dianggap sebagai penghalang serius bagi upaya melaksanakan penuaian. Yesus telah berhasil menerobos ketiga penghalang tersebut. Itu sebabnya, perbedaan apa pun di antara si penuai dengan tuaian haruslah tidak menjadi alasan untuk mengerjakan penuaian. Yang utama adalah bahwa kabar kasih karunia Allah haruslah diberitakan kepada panta ta ethne (segala suku bangsa). Injil harus menembus batas gender, etnis, pemahaman teologis dan bahkan segala batas apa pun lainnya.

2. Lokasi Penuaian. Penuaian berlangsung di suatu lokasi tertentu. Yesus dan perempuan Samaria dipertemukan di sumur Yakub. Sepintas terkesan perjumpaan itu terjadi secara tidak sengaja, namun dalam perspektif Allah, tentu perjumpaan tersebut bukan sebuah kebetulan, melainkan ada dalam rancangan Allah. Sumur Yakub merupakan tempat strategis bagi perjumpaan mereka berdua. Orang Yahudi maupun orang Samaria sama-sama menjadi anakanak Yakub. Sumur Yakub menjadi tempat bersejarah bagi keduanya. Ikatan historis tersebut menjadi ruang strategis terjadinya dialog interaktif yang efektif. Selain ikatan historis, sumur juga menjadi tempat strategis bagi tersedianya kebutuhan dasar manusia yaitu 'air'. Karena itu selanjutnya, percakapan Yesus difokuskan tentang kebutuhan air, dari yang bersifat jasmani, hingga kebutuhan air surgawi. Berdasarkan pengalaman tersebut, maka yang menjadi pertanyaan penting kita tentang lokasi penuaian masa kini ada dua: apakah lokasi penuaian itu memiliki ikatan historis? dan apakah lokasi penuaian itu memiliki ikatan kebutuhan yang paling mendasar? Dr. Ichwei G. Indra merancang bangun teologi yang ia sebut dengan "Teologi Air Sumur" berdasarkan Yohanes 4. Menurutnya, sumur masih menjadi sumber yang menyediakan kebutuhan pokok sehari-hari. ${ }^{1}$ Ini merupakan salah satu contoh bagaimana memanfaatkan potensi lokal sebagai titik temu dengan Injil.

\footnotetext{
${ }^{1}$ Ichwei G. Indra, Teologi Air Sumur (Surabaya: Pelayanan Mandiri Mikhael, 2010), 8
} 
3. Karakteristik Tuaian. Bila menganalisis secara lebih mendalam tentang perempuan Samaria sebagai 'tuaian', maka dapat ditemukan beberapa karakteristik yang dapat menjadi model bagi identitas tuaian masa kini. Pada dasarnya perempuan Samaria tersebut adalah pribadi yang sedang mengalami krisis. Pertama, ia sedang mengalami 'krisis kebutuhan dasar' yaitu air minum sebagai kebutuhan hidup sehari-hari. Kedatangannya di siang hari bolong ke sumur Yakub mengindikasikan adanya kebutuhan dasar yang mendesak yang harus dipenuhi. Kedua, perempuan Samaria itu juga mengalami 'krisis moral'. Ia seorang perempuan yang melakukan praktik 'Poliandri' yang oleh masyarakat setempat dan masyarakat pada umumnya dianggap sebagai perbuatan a-moral. Ketiga, perempuan Samaria juga sedang mengalami 'krisis psikologis'. Sejujurnya secara implisit, ia sedang dihantui rasa malu dan takut terhadap komunitasnya sendiri. Itu juga sebabnya ia pergi ke sumur pada jam 12 siang dimana pada waktu itu tidak biasa orang mengambil air di sumur. Ia berharap pada jam itu ia tidak menjumpai siapa pun di sumur itu. Keempat, perempuan Samaria itu juga sedang mengalami 'krisis spiritual'. Percakapannya dengan Yesus membukakan jatidirinya secara rohani bahwa ia telah menyembah allahnya di gunung-gunung. Namun Yesus mengarahkannya untuk menjadi penyembah Allah dalam 'roh dan kebenaran'.

Yesus Kristus sendiri memang datang ke dalam dunia tepat pada waktunya, yaitu ketika bangsa Yahudi sedang mengalami multi krisis dalam kehidupannya secara politis, ekonomis, sosial, budaya dan spiritual. Mereka sedang menjadi bangsa jajahan kekaisaran Romawi dimana budaya Yunani-Romawi menguasai lapisan masyarakat. Akibatnya, mereka tertindas secara politis yang berdampak pada aspek sosial, ekonomi dan spiritualitas mereka.

Pada masa kini kita juga menghadapi karateristik realitas yang serupa. Dalam konteks Indonesia saja krisis ekonomi ditandai dengan tingkat kemiskinan mencapai $11.2 \%$ atau terdapat 28,59 juta masyarakat miskin. Secara moral, frekuensi perceraian mencapai 40 kasus per jam. Selain itu, $80 \%$ pasangan suami-isteri disebut sedang dalam keadaan "seperti api dalam sekam". Artinya, 80\% pasangan suami-isteri sedang dalam tahap hubungan yang bermasalah, riskan dan berpotensi pada terjadinya perceraian. Bahkan data dunia menyebutkan bahwa peringkat Sepuluh besar tingkat perceraian tertinggi justru terjadi di negara-negara Kristen. Ditambah lagi, hingga tahun 2013 saja sudah terjadi Kekerasan Dalam Rumah Tangga (KDRT) sebanyak 11.719 kasus. Sedangkan pengguna narkoba di 
tahun 2015 telah mencapai 5,8 juta jiwa. Berbarengan dengan itu, setidaknya terdapat 64\% dari pekerja di Indonesia yang mengalami stress. Kondisi multi krisis tersebut memberi gambaran tentang karakteristik tuaian yang ada pada masa kini. Satu sisi krisis tersebut telah membuat penderitaan masyarakat, namun sekaligus justru menjadi 'peluang' bagi pemberitaan kabar baik. Tuhan sudah membajak lahannya dan menanam benihnya, dan kitalah yang dipersiapkan untuk menuainya.

4. Strategi Penuaian. Untuk dapat melakukan penuaian secara efektif, diperlukan suatu strategi yang tepat. C. Peter Wagner mendefinisikan strategi sebagai "cara yang dapat dipakai untuk mencapai sasaran yang telah ditentukan sebelumnya". ${ }^{2}$ Teks Yohanes 4 kita belajar strategi dari segi tempat, waktu, obyek, dan metode penuaian. Pertama, perlu penetapan tempat yang tepat. Yesus 'harus' melewati daerah Samaria. Kata 'harus' menunjukkan aspek 'kewajiban' yang mengandung unsur 'keterpaksaan' yang tidak terelakkan. Barangkali itulah satu-satunya jalan terdekat yang paling efektif dalam route perjalanan pelayanan Yesus. Dalam strategi penuaian, penetapan tempat yang tepat ini dapat dipahami dalam dua model, yaitu: pertama, menetapkan suatu wilayah tertentu sebagai target penuaian (suku, bangsa, negara). Kemudian diutuslah penuai ke tempat tersebut (bnd. Mat 28:19-20). Model kedua, penetapan tempat berlangsung secara alamiah mengikuti alur profesi atau penetapan tempat untuk hidup (mis: kisah Yusuf, dan Daniel cs). Jadi dimana pun seorang Kristen ditempatkan di situlah menjadi tempat penuaian baginya (bnd. Yer 29:7). Penuaian pada masa kini juga harus memberi perhatian serius terhadap penetapan tempat. C. Peter Wagner menegaskan tentang hal ini,"Tidak ada yang lebih berpengaruh terhadap keberhasilan atau kegagalan proyek penanaman gereja anda selain pemilihan tempat yang tepat...lokasi yang baik akan menutupi banyak sekali kegagalan". ${ }^{3}$ Kedua, strategi penetapan waktu yang tepat. Tuaian selalu terjadi pada 'waktu Tuhan' (kairos). Yesus menuai pada jam 12 siang ketika panas terik matahari menyengat yang menyebabkan kehausan yang perlu segera dipuaskan dengan meminum air. Itulah saat yag tepat bagi perempuan Samaria untuk mendengar Injil dan menerima keselamatan. Penuaian masa kini dapat dilakukan dengan membuat perencanaan waktu berdasarkan hasil survey atas kondisi masyarakat di tempat tertentu. Cara lain penuaian

\footnotetext{
${ }^{2}$ C. Peter Wagner, Strategi Pertumbuhan Gereja (Malang: Gandum Mas, 1996), 14.

${ }^{3}$ C. Peter Wagner, Penanaman Gereja Untuk Tuaian Yang Lebih Besar (Jakarta: Harvest Publication House, 1995), 102.
} 
terjadi secara 'spontan' dalam waktu yang tidak direncanakan dengan sengaja oleh para penuai. Menurut tradisi Yahudi musim menuai akan terjadi beberapa bulan lagi. Namun Yesus menyatakan kepada murid-murid-Nya, "sekaranglah tiba saatnya untuk menuai". Artinya, penuaian jenis ini, tidak mengikuti sistem baku yang secara sistematis (kronos) berlangsung tertata, terukur dan terencana. Ketika Allah bekerja menyelamatkan seseorang, maka pada saat itulah tiba waktunya untuk menuai. Ketiga, penetapan titik kontak yang tepat. Startegi penting dalam penuaian adalah menemukan point of contact. Titik pijak awal untuk memulai komunikasi dengan tuaian. Yesus menggunakan sumur Yakub sebagai titik kontak yang mempertemukan kontinyuitas historis umat Israel (penggenapan janji Abraham: Kej 12: 2-3) dan kebutuhan riil masa kini (air). Untuk menemukan titik kontak tersebut diperlukan kepekaan terhadap karya Tuhan dan kepekaan terhadap konteks realitas masa kini yang sedang dihadapi. Untuk itu diperlukan juga kreatifitas secara aktif untuk mencari titik kontak tersebut. Keempat, Penetapan metode yang tepat. Yesus menggunakan metode dialogis untuk menerobos kedalaman hati perempuan Samaria. Melalui metode dialog itu, Yesus dapat melaksanakan tahap-tahap untuk mengurai problematika kehidupan perempuan Samaria itu. Pertama-tama, Yesus mempercakapkan mengenai krisis kebutuhan jasmani yaitu 'air' sebagai topik percakapan yang kontekstual. Tahap berikutnya, Yesus memasuki ruang moralitas perempuan Samaria dimana ia memang sedang mengalami krisis moral. Dengan itu, perempuan Samaria mulai berani membuka dirinya dengan jujur dan benar. Krisis moral berdampak pada krisis psikis yaitu adanya 'rasa malu' dan 'rasa takut' untuk bertemu orang lain. Keterbukaannya dengan Yesus menunjukkan perempuan Samaria mulai berhasil mengatasi rasa malu dan takut tersebut. Tahap terakhir, Yesus menembus ruang spiritualitas perempuan Samaria. Yesus mempercakapkan isu tentang 'pusat penyembahan' kepada Allah yang benar (di gunung? di Yerusalem?) dan menggiringnya kepada esensi penyembahan yang benar yaitu "dalam roh dan kebenaran" (4:23). Sampai di sini, perempuan Samaria dibawa kepada sebuah 'pengakuan' tentang Yesus sebagai Mesias yaitu pribadi yang sedang dinanti-nantikan kedatangannya oleh umat Israel. Dengan menembus dimensi spiritual, Yesus akhirnya berhasil membuat perempuan Samaria mengaku percaya kepada-Nya.

Penetapan metode yang tepat merupakan bagian dari langkah sukses penuaian. Dalam hal ini diperlukan kreatifitas, pengetahuan, dan analisis konteks yang memadai. Metode yang 
tepat menjadi 'alat bedah' yang efektif untuk menembus ruang-ruang jatidiri tuaian dan membawanya kepada Kristus.

5. Hasil Penuaian. Tuaian yang dihasilkan segera menunjukkan tanda-tanda yang nyata yaitu adanya Transformasi. Istilah 'transformasi' tidak asing lagi bagi masyarakat masa kini. Kata terbentu dari kata trans yang berarti: 'dari satu sisi ke sisi yang lain (cross) dan kata form artinya 'bentuk. Jadi 'trasnformasi' berarti perubahan bentuk yang lebih dari, atau melampaui perubahan bungkus luar saja. ${ }^{4}$ Dialog Yesus dengan perempuan Samaria juga mneghasilkan transformasi orientasi hidup, moral, psikis, dan spiritual. Pertama, Transformasi orientasi hidup. Mula-mula perempuan Samaria ke sumur dengan tujuan utama untuk mengambil air, karena itu ia membawa tempayan. Namun setelah percakapan dengan Yesus secara mendalam, ia tidak lagi menganggap air sebagai prioritas yang harus diutamakan. Ia justru "meninggalkan tempayannya di situ dan pergi ke kota" (4:28). Tindakan itu menunjukkan adanya perubahan orientasi hidup. Seseorang yang yang telah mengalami perjumpaan pribadi dengan Yesus akan mengalami perubahan orientasi hidupnya. Ia mengalami perubahan pembaharuan budi (Rm 12:1-2). Rasul Paulus menyatakan,’hidupku bukannya aku lagi, melainkakn Kristus di dalamku” (Gal 2:20). Kedua, Transformasi Moral. Ketika Yesus menyentuh moralitasny, perempuan itu tidak dapat mengelak lagi dan menyembunyikan perbuatan a-moralnya. Ia pun mengakui dengan terbuka dan jujur, sehingga Yesus pun memberi apresiasi dengan mengatakan,"...dalam hal ini engkau berkata benar..." (4:18). Keterbukaan dan Kejujuran telah membuat perempuan Samaria terbebas dari tuntutan moralitas yang menekannya. Hal itu bersesuaian dengan pengakuan jujur tentang dosa sebagai syarat untuk menerima pengampuan dosa (1Yoh 1:9). Ketiga, Transformasi Psikologis. Dialog dengan Yesus telah mentransformasi hambatan psikiologis perempuan Samaria. Ia yang tadinya dikuasai rasa malu dan takut, sekarang justru berani tampil di kota Sikhar dan memberitakan secara terbuka mengenai perjumpaannya dengan Yesus, Sang Mesias. Keberaniannya berbicara di depan umum menunjukkan bahwa ia mengalami transformasi psikologis dalam dirinya. Dengan melakukan kebenaran seseorang akan mengalami kemerdekaan dalam jiwanya (bnd. Yoh 8:32). Keempat, Transformasi Spiritual. Ini menjadi transformasi yang paling mendasar, sebagaimana nyata dalam diri perempuan

\footnotetext{
${ }^{4}$ G. Sudarmanto, Menjadi Pelayan Kristus Yang Baik (Batu: Dept. Multimedia YPPII, 2009), 75
} 
Samaria. Setelah dialognya dengan Yesus, ia akhirnya sampai pada perubahan paradigma spiritualnya. Ia tidak lagi memercayai allah-allahnya, tetapi mengakui Yesus sebagai Sang Mesias baginya (bnd. Why 3:20). Bukan itu saja, ia pun memberitakan Yesus kepada penduduk kota Sikhar (bnd. Kis 1:8).

\section{- Penutup:}

Di zaman ini, manusia sedang mengalami krisis multidimensional yang mencakup aspek ekonomi, moral, psikologis, dan spiritual. Krisis tersebut telah memakan banyak korban. Berjuta manusia binasa tanpa Kristus. Itu sebabnya, adanya krisis tersebut justru menjadi kesempatan bagi penuaian jiwa-jiwa baru bagi kristus. Oleh karena itu, ada dua pertanyaan kontekstual dari para murid kepada Yesus yang dapat menjadi pertanyaan laten dan paten di sepanjang zaman (4:27), yaitu:

- Apa yang Engkau kehendaki?

- Apa yang engkau percakapkan dengan dia?

Kedua pertanyaan tersebut dapat berlaku di setiap zaman. Kita harus terus bertanya kepada Tuhan mengenai 'kehendak Tuhan'. Kita perlu bimbingan-Nya untuk sungguh-sungguh mengenali apa yang Dia kehendaki untuk kita lakukan pada zaman ini. Penuaian yang benar hendaknya berlangsung dalam kehendak-Nya. Hal itu menghindarkan kita dari praktik penuaian yang semu, salah, dan gegabah yang justru akan menjadi bumerang bagi diri kita sendiri. Praktik penuaian yang salah itu biasanya lebih dikuasai oleh semangat berlebihan, militansi semu, arogansi institusi dan pemahaman yang dangkal. Bila hal itu dibiarkan terus berlangsung, maka justru akan merusakkan tuaian yang sesungguhnya sudah siap untuk dituai.

Bersamaan dengan itu, kita pun juga harus bertanya,"Apa yang engkau percakapkan..." Pertanyaan itu menolong kita untuk mengenali topik-topik apa yang cocok, aktual dan relevan untuk diangkat menjadi percakapan yang berdampak pada transformasi total. Kekristenan harus membuka ruang bagi kemungkinan dialog terbuka tentang kemanusiaan yang akan membuka jalan bagi Injil kasih karunia Allah. 
Krisis multi dimensi memerlukan solusi komprehensif yang dapat menyentuh semua aspek kehidupan manusia masa kini sebagai obyek penuaian. Untuk itu pendekatan yang bersifat holistik sangat dibutuhkan, sehingga sangat penting dan mendesak untuk segera dikerjakan berbagai bentuk Hollistic Ministry sebagai upaya kontekstual untuk menjangkau masyarakat modern sebagai tuaian masa kini. 